\title{
Red Blood Cells Product
}

National Cancer Institute

\section{Source}

National Cancer Institute. Red Blood Cells Product. NCI Thesaurus. Code C133280.

Red blood cells remaining after separating plasma from human blood, or collected by apheresis. 